\title{
The influence of film and experiential pedagogy on multicultural counseling self-efficacy and multicultural counseling competence
}

\author{
Jennifer H. Greene ${ }^{1}$, Sejal M. Barden ${ }^{2}$, Edrica D. Richardson ${ }^{3}$, and Kristopher G. Hall ${ }^{4}$ \\ Abstract: Scholarly discourse has emphasized the need for culturally competent \\ practices. Additionally, multicultural self-efficacy has been found to be critical in \\ working with clients from diverse backgrounds, however, there is a relative paucity \\ of literature on how to teach counselor trainees to be culturally competent and self- \\ efficacious (Kim \& Lyons, 2003). The use of experiential education is one \\ pedagogical tool that has been supported in effectively connecting multicultural \\ theory to practice (Arthur \& Achenbach, 2002; Coleman, 2006). In this study, \\ researchers investigated the influence of experiential pedagogical strategies with \\ an emphasis on film on multicultural counseling competence (MCC) and \\ multicultural counseling self-efficacy (MCSE). Results indicated that both MCC \\ and MCSE increased as a result of one semester in a multicultural counseling class. \\ Additional findings and limitations are discussed.
}

Keywords: Multicultural Competence, Multicultural Counseling Self-Efficacy, Experiential Pedagogy

\section{Introduction}

Counseling as a profession emphasizes diversity training in preparation standards (Counsel for Accreditation of Counseling and Related Educational Programs [CACREP], 2009) and cultural competence in ethical standards (American Counseling Association [ACA], 2005); however, few counselor preparation programs have employed effective methods to train counselors how to therapeutically connect with people from culturally diverse backgrounds (Alexander, Kruczek, \& Ponterotto, 2005; Coleman, 2006; Sue, 1981). Although there has been an increase in literature on the need for culturally competent practices, there is a relative paucity of literature on how to teach counselor trainees to be culturally competent (Kim \& Lyons, 2003). Traditional pedagogical methods in the counseling profession have typically originated from a European- Western perspective, operating primarily within monocultural and monolingual frameworks, which can be ineffective when working with people from diverse backgrounds (Sue, Arredondo, \& McDavis, 1992).

To competently practice, counselors must be self-efficacious or confident in their ability to practice a given set of tasks (Bandura, 1999). Multicultural counseling self-efficacy (MCSE) and multicultural counseling competence (MCC) are necessary for counselor trainees (Constantine \& Ladany, 2000). One way MCC and MCSE are fostered is through assignments and activities in

\footnotetext{
${ }^{1}$ Department of Counseling, Leadership, Adult Education, and School Psychology, Texas State University, College of Education, 601 University Drive

San Marcos, TX 78666, jhg45@,txstate.edu

2 Department of Child, Family and Community Sciences, University of Central Florida, College of Education and Human

Performance, Sejal.Barden@ucf.edu

3 Broward College, erichard@broward.edu

${ }^{4}$ University of San Diego, School of Leadership and Education Sciences, Kghall@sandiego.edu
} 
which students directly engage in an experiential learning process where they examine, expand and question their cultural assumptions, acquiring affective, behavioral, and cognitive shifts (Cordero \& Rodriguez, 2009; Weaver, 2005). Films and media are frequently used in multicultural counseling courses (Villalba \& Redmond, 2008), however the efficacy of this pedagogical strategy in increasing MCC and MCSE is not known. Therefore, the purpose of this investigation was to determine the effect of a one-semester experiential multicultural counseling class that emphasized film as the primary pedagogical intervention on counseling students' MCC and MCSE.

\section{Multicultural Counseling Competence and Multicultural Counseling Self-Efficacy}

By 1982, CACREP had been petitioned to recognize multicultural counseling (Bobby, 2013) and in 1993 CACREP included multicultural guidelines in their accreditation standards (Dinsmore \& England, 1996) yet graduates of counselor preparation programs have historically reported feeling unprepared to counsel clients from culturally diverse backgrounds (Arthur \& Achenbach, 2002; D’Andrea \& Daniels, 2001; Ponterotto, 1997), indicating that despite training, counselors' MCSE is low. Researchers (Constantine, 2001; Orlinsky, Grawe, \& Parks, 1994) find that low self-efficacy leads to higher levels of anxiety and a decrease in a counselor's ability to form a therapeutic relationship with clients. On the other hand, higher self-efficacy is related to perseverance when faced with challenging counseling tasks (Larson \& Daniels, 1998). Therefore, low MCSE may lead to higher levels of anxiety when working with clients from a different background and a decreased ability to develop therapeutic cross-cultural relationships, with higher MCSE being related to persisting when faced with challenges within the cross-cultural counseling relationship.

\section{Experiential Education in Multicultural Pedagogy}

Gaps in the literature on effective pedagogy targeted at increasing MCSE and MCC for counselor trainees highlight the need for further empirical research into effective pedagogical strategies aimed at increasing competence and efficacy when working with clients from diverse backgrounds. Researchers (Collins \& Pieterse, 2007) indicate that pedagogical methods for multicultural training remain primarily within the cognitive domain, rarely extending into the affective domain, although the MCC competencies highlight the need for individuals to engage in both cognitive and affective processes (Sue, Arredondo, \& McDavis, 1992). Additionally, by primarily focusing on the cognitive/knowledge domains of cultural competence, educators fail to adhere to a key aspect in competency development, self-awareness (Priester et al., 2008). Arredondo \& Toporek (2004) suggested that knowledge alone does not lead to behavior or attitude change among counselor trainees, therefore reinforcing culturally insensitive practices.

The use of experiential education is one pedagogical tool that has been supported in effectively connecting multicultural theory to practice, offering an avenue for students to challenge personal beliefs and behavior patterns, in both cognitive and affective domains (Arthur \& Achenbach, 2002; Coleman, 2006; DeRicco \& Sciarra, 2005; Heppner \& O'Brien, 1994; Kim \& Lyons, 2003). Researchers (Barden \& Cashwell, 2014; Collins \& Pieterse, 2007; Hill, 2003; Tyler \& Guth, 1999; Villalba \& Redmond, 2008) and students support the inclusion of experiential pedagogies in counselor preparation programs that expose students to diverse worldviews and encourage cultural sensitivity. Heppner and O'Brien (1994) investigated student perceptions of the most helpful and most hindering aspects of their multicultural training. Results indicated that 
the most helpful events were experiential components, whereas the most hindering was the students' feeling of inability to integrate all of the knowledge gained. Likewise, Coleman (2006) discovered that the areas that students describe as being influential are all experiential in nature. Furthermore, Arthur and Achenbach (2002) state that experiential learning can be used to go beyond cognitive learning to raise awareness about cultural issues, help to develop cultural empathy and challenge and restructure students' personal schemas. The use of film to elicit feelings and values is one common experiential strategy in multicultural courses (Koch \& Dollarhide, 2000).

\section{Use of Film}

Using film as a form of experiential learning in counselor education is not a new concept (Gladstein \& Feldstein, 1983; Koch \& Dollarhide, 2000), and recent professional literature builds on that by providing guidelines for using films in a variety of subject matter such as ethics, psychopathology, diagnosis, group work, diversity awareness, and skill building (Chambliss \& Magakis, 1996; Koch \& Dollarhide, 2000; Pinteritis \& Atkinson, 1998; Villalba \& Redmond, 2008). Furthermore, counseling students report gaining valuable knowledge and awareness from the use of experiential activities including film used in multicultural counseling courses (Hays, Dean, \& Chang, 2007).

Examples of use of film include Koch and Dollarhide's (2000) use of scenes from Good Will Hunting, in a counseling theories class to highlight the therapeutic relationship, counseling techniques used, and ethical concerns. Good Will Hunting is a film about a young man from a troubled background who was working as a janitor when discovered as a math genius and who navigates some tough decisions with the help of a counselor. Additionally this film could be utilized in a multicultural class to examine similarities and differences in cultural backgrounds for the counselor and client who both come from working families and grew up in the same neighborhood (Koch \& Dollarhide, 2000). Another example is the use of the popular film Crash to examine stereotypes. Villalba and Redmond (2008) qualitatively investigated the use of Crash as a pedagogical tool to encourage students to share their preconceived and potentially internalized assumptions about people from diverse backgrounds.

The premise of Crash involves two literal car crashes to emphasize figurative crashes as lives intersect in scenes highlighting how misunderstandings and assumptions about race, ethnicity, and religion can result in misunderstandings and tragedy. More specifically, the film includes characters from diverse ethnic, economic, racial and religious backgrounds and can be used elicit and encourage difficult conversations on the state of diversity in the United States. Results from the study indicated that the majority of students' believed viewing and processing the film was effective in preparing students to discuss difficult topics throughout the semester. The authors conclude that there is a need for research investigating the effectiveness of film in developing multicultural counselor attributes and professional development for counselor trainees (Villalba \& Redmond, 2008). In addition to using film in multicultural and diversity training to elicit emotional responses such as Crash, comedies such as the 2006 film Outsourced or My Big Fat Greek Wedding can also be utilized to examine and discuss cultural differences (Briam, 2010; Pandey, 2012). Although films cannot substitute for actual interaction with members of other cultures, they can provide useful preparation for those encounters by fostering understanding and developing sensitivity (Roell, 2010). 
Film has been used to positively impact ethnic identity development, specifically in the areas of students' sense of belonging and in ethnic identity exploration (Rorrer \& Furr, 2009). Racial/ethnic identity development significantly interacted with multicultural training to impact multicultural knowledge (Chao, 2012). In other words, multicultural education changed the relationship between racial/ethnic identity and multicultural knowledge (Chao, 2012). A multicultural seminar utilized movies and found a positive change in ethnic identity development among college freshmen (Rorrer \& Furr, 2009). Using film, which leads to positive changes in racial/ethnic identity development, may therefore also impact multicultural knowledge, one of the three areas of multicultural counseling competence.

In sum, researchers (Hays et al., 2007; Villalba \& Redmond, 2008, Rorrer \& Furr, 2009) have provided initial support for the use of film as an experiential tool in multicultural courses, however limited research exists on the effectiveness of film in increasing MCC and MCSE for counselor trainees. Additionally, researchers (D'Andrea, Daniels, \& Heck, 1991) indicate that a multicultural counseling class increases MCC. Therefore, this research looked at the impact of the use of film as a pedagogical strategy in a one-semester experientially based multicultural counseling class on students' MCSE and MCC.

\section{Intervention}

\section{Pedagogical Philosophy}

The pedagogical approach utilized was primarily focused on creating a safe space for students to learn from each other and together. Teaching multicultural sensitivity is extremely complex, potentially volatile, and may also be transformative, so intentionally inviting graduate counseling students to explore the challenging aspects of diversity such as oppression and prejudice must be done in an atmosphere of respect and acceptance throughout the course. The liberation pedagogical model allows for that with it's six tenants of creating community, intentionality and being aware of person of the therapist, creating a safe place, collaboration between learner and teacher, use of humor, and maintaining a therapeutic perspective (Nixon et al, 2010). Creating a safe place requires an open and transparent environment to facilitate honest sharing without punishment. The creation of a safe space involves the entire class to function as a community, which, according to Zamboanga and Binman (2001), is an essential goal for multicultural leaning. To create a community that honored all voices and ensured all were heard, the more traditional classroom power structure was not utilized, but replaced by a flattened teacherstudent hierarchy (Locke \& Kiselica, 1999).

\section{Multicultural Counseling Class}

The multicultural counseling course is required of all master's level counseling students over either a 12 or 15 -week semester of required course work. The course is offered twice per academic year, and meets weekly for approximately either 3 hours and 50 minutes or 2 hours 50 minutes, depending on the length of the semester. Descriptions of the class and objectives are listed in the syllabus at the beginning of the semester.

The films utilized in the class were selected intentionally to connect to the development of specific multicultural counseling competencies (Arthur \& Achenbach, 2002). The films were utilized for specific purposes such as challenging stereotypes (e.g. Crash, Race: The Power of an 
Illusion) or facing a clash in cultural identities (e.g. Real Women Have Curves) unlike a film studies class that analysis the structure of the film itself. These films were chosen to evoke emotion and though. The first class session involved an icebreaker activity to acknowledge prejudice and then viewing of the film Crash (Cheadle \& Haggis, 2004) in its entirety. Approximately 50\% of the students in class had seen Crash previously. Students, who previously viewed the film, were instructed to watch it through their therapeutic lens as counselors in training. Students were asked to write down diversity issues they noticed in the film and any part(s) that they found themselves reacted to emotionally. Finally, there was an instructor led discussion at the end of class after viewing the film and at the beginning of the second class-session.

Throughout the semester several additional films were used as experiential tools particularly to address the awareness aspect of the tripartite model of MCC. Films such as Race: The Power of an Illusion (Herbes-Sommers, 2003; Smith, 2003; Strain (2003), Real Women Have Curves (Atlas, Brown, \& LaVoo, 2002), and The Longest Hatred (Dor-Ner, 1993) were utilized to illustrate challenging aspects of cultural diversity such as navigating between two cultures and history of oppression. Race: The Power of an Illusion is a three-part documentary that highlights the lack of biological determinants for race, the historical and social evolution of the concept of race, and the privilege and oppression that are associated with dividing people racially. Real Women Have Curves shows the dilemma a young Mexican girl experiences when she has to navigate the traditional expectations of her Mexican family and the opposing aspirations of her American peers. This movie can be used to facilitate cross-cultural perspective taking (Minton, 2011). The Longest Hatred focuses on the origins of prejudice, oppression, and genocide faced by those of Jewish descent in Europe and highlights worldwide spread of anti-Semitism. See Table 1 for a brief summary of other potential films to consider integrating as experiential tools in a multicultural course.

A culminating experiential activity of the semester involved the students creating their own film of an interview they conducted with someone from another cultural group. The purpose was to challenge students to learn more about a cultural group that they knew little about and that they might struggle to understand; this could be a source of potential personal prejudice. This experiential activity was designed to tie together the emphasis on film with the experiential nature of the class. It was intended to allow students to gain both knowledge of another cultural group, awareness of their own reactions, and skills to communicate effectively with someone from a background different from their own. Students were tasked to create their own interview questions and likewise, their own process questions to further aid in reflective learning. The presentation of the excerpts from the videos was often emotional as students expressed discomfort and even shame as they discovered and revealed their own prejudices.

Debriefing / Reflection. When providing students with hands on experiences, it is essential to also provide opportunities for students to reflect on the experience (Kolb, 1984). Arthur and Achenbach (2002) described debriefing as a process through which students can be supported in transforming their personal discoveries into professional implications for their future work as counselors working with culturally diverse clients. Many experiential activities involve increasing personal and interpersonal awareness and debriefing helps students to apply the awareness gained from an activity to their lives outside the activity and the classroom (Achenbach \& Arthur, 2002). Additionally, debriefing helps students to learn from others, to increase reflection about their own personal reactions, to help resolve emotional arousal associated with the learning experience, and to provide closure to their experience (Achenbach \& Arthur, 2002). Debriefing and reflection were important components of each of the experiential activities utilized in the course as that 
Greene, J.H., Barden, S.M., Richardson, E.D., \& Hall, K.G.

transformed the activity from simply being an interesting way to pass time to a learning experience that is meaningful after the activity is over and outside of class.

Table 1

Suggested Films for Multicultural Counseling Training

\begin{tabular}{|c|c|c|}
\hline Film title & Summary & Key Issues \\
\hline Crash (2004) & $\begin{array}{l}\text { Crash involves two literal car crashes to emphasize } \\
\text { figurative crashes as lives intersect in scenes } \\
\text { highlighting how misunderstandings and assumptions } \\
\text { about race, ethnicity, and religion can result in } \\
\text { misunderstandings and tragedy. More specifically, the } \\
\text { film includes characters from diverse ethnic, } \\
\text { economic, racial and religious backgrounds and can } \\
\text { be used elicit and encourage difficult conversations on } \\
\text { the state of diversity in the United States }\end{array}$ & Racism, Classism, Sexism \\
\hline $\begin{array}{l}\text { Do the Right Thing } \\
\text { (1989) }\end{array}$ & $\begin{array}{l}\text { Spike Lee's drama takes place in the Bedford- } \\
\text { Stuyvesant neighborhood of Brooklyn New York. } \\
\text { Racial tensions run high during an unseasonably hot } \\
\text { summer day, causing loyalties to be tested and hard } \\
\text { decisions to be made. }\end{array}$ & Racism \\
\hline Glory (1989) & $\begin{array}{l}\text { The film that landed Denzel Washington his first } \\
\text { Academy Award, Glory follows the first all Black } \\
\text { regimen of the Union Army during the Civil War. } \\
\text { Seen as less than human, these brave men fight for the } \\
\text { colonies freedom from the British while fighting for } \\
\text { freedom from oppression. }\end{array}$ & Racism \\
\hline $\begin{array}{l}\text { How to Make an } \\
\text { American Quilt } \\
\text { (1995) }\end{array}$ & $\begin{array}{l}\text { Finn Dodd has come to a crossroads in her life and } \\
\text { isn't sure how to proceed. Contemplating a marriage } \\
\text { proposal and finishing a thesis, she takes refuge at her } \\
\text { grandmother's home where she meets a group of } \\
\text { women who happen to be making a quilt for her } \\
\text { wedding. }\end{array}$ & Sexism \\
\hline $\begin{array}{l}\text { Last Chance for } \\
\text { Eden (2003) }\end{array}$ & $\begin{array}{l}\text { This is a documentary film featuring nine women and } \\
\text { men discussing issues of diversity, racism, and sexism } \\
\text { in the workplace. Throughout the course of a } \\
\text { weekend, the participants address stereotypes and how } \\
\text { they have affected every aspect of their lives. }\end{array}$ & Racism, Sexism \\
\hline $\begin{array}{l}\text { Miss Evers'Boys } \\
\text { (1997) }\end{array}$ & $\begin{array}{l}\text { Told from the point of view of Nurse Eunice Evers, } \\
\text { this film details what happened to a group of men who } \\
\text { are under her care. This film details the effects of the } \\
\text { Tuskegee experiment and how it impacted the lives of } \\
\text { not only the participants, but a whole town. }\end{array}$ & Racism \\
\hline $\begin{array}{l}\text { Race: The Power of } \\
\text { an Illusion (2003) }\end{array}$ & $\begin{array}{l}\text { A three-part documentary that highlights the lack of } \\
\text { biological determinants for race, the historical and } \\
\text { social evolution of the concept of race, and the } \\
\text { privilege and oppression that are associated with } \\
\text { dividing people racially }\end{array}$ & Racism, Privilege \\
\hline Ray (2004) & $\begin{array}{l}\text { A biographical film focusing on } 30 \text { years of the life } \\
\text { and career of rhythm and blues musician Ray Charles. }\end{array}$ & Physical disabilities \\
\hline
\end{tabular}

Journal of the Scholarship of Teaching and Learning, Vol. 14, No. 5, December 2014. 


\begin{tabular}{|c|c|c|}
\hline $\begin{array}{l}\text { Real Women Have } \\
\text { Curves (2002) }\end{array}$ & $\begin{array}{l}\text { Shows the dilemma a young Mexican girl experiences } \\
\text { when she has to navigate the traditional expectations } \\
\text { of her Mexican family and the opposing aspirations of } \\
\text { her American peers }\end{array}$ & Cultural \\
\hline $\begin{array}{l}\text { Schindler's List } \\
\text { (1993) }\end{array}$ & $\begin{array}{l}\text { Set in World War II Poland, Oskar Schindler is a } \\
\text { German businessman who's looking to make his } \\
\text { fortune from the war. Instead of gaining riches, he } \\
\text { gains compassion for the many Jewish people who he } \\
\text { employs as "skilled" workers. }\end{array}$ & Racism \\
\hline $\begin{array}{l}\text { The Boondocks (TV } \\
\text { series 2005-) }\end{array}$ & $\begin{array}{l}\text { After working hard for several years, Robert } \\
\text { "Grandad" Freeman finally saves enough money to } \\
\text { move his family to Woodcrest in the suburbs. His } \\
\text { militant grandson Huey Freeman and his aspiring } \\
\text { gangster brother Riley, find themselves adapting to a } \\
\text { world that's very different from their Chicago } \\
\text { neighborhood. }\end{array}$ & Racism, Sexism, Ageism \\
\hline $\begin{array}{l}\text { The Joy Luck Club } \\
\text { (1993) }\end{array}$ & $\begin{array}{l}\text { A film adaptation of Amy Tan's } 1989 \text { novel, it is the } \\
\text { story of four Chinese women and their Chinese- } \\
\text { American daughters. Struggling to understand each } \\
\text { other, the film unfolds and gives insight to each } \\
\text { character's unique experience and how to bridge the } \\
\text { generational divide. }\end{array}$ & Ageism, Sexism \\
\hline $\begin{array}{l}\text { The Longest Hatred } \\
\text { (1993) }\end{array}$ & $\begin{array}{l}\text { Focuses on the origins of prejudice, oppression, and } \\
\text { genocide faced by those of Jewish descent in Europe } \\
\text { and highlights worldwide spread of anti-Semitism. }\end{array}$ & Prejudice, Anti-Semitism \\
\hline $\begin{array}{l}\text { The Other Sister } \\
\text { (1999) }\end{array}$ & $\begin{array}{l}\text { A romantic comedy about an ambitious mentally- } \\
\text { challenged young woman who returns home after } \\
\text { graduating from a sheltered boarding school. She falls } \\
\text { in love and is able to gain more independence from } \\
\text { her over-protective mother. }\end{array}$ & Intellectual disabilities \\
\hline $\begin{array}{l}\text { The Tuskegee } \\
\text { Airmen (1995) }\end{array}$ & $\begin{array}{l}\text { Fighting for democracy while simultaneously fighting } \\
\text { for equality, the Tuskegee Airmen tells the story of the } \\
\text { first all African-American fighter pilot squad. }\end{array}$ & Racism \\
\hline
\end{tabular}

\section{Methods}

\section{Participants}

Participants for the study were selected due to enrollment in a multicultural counseling class. All participants were from one university located in the Southeastern United States. Students were invited to participate on their first night of class by researchers who were not instructors in the class and the instructor was not informed which students chose to participate. Participation was voluntary and efforts were made to protect the confidentiality of participants including having the students label assessment packets with a four-digit code rather than their names. The intention was that the same four-digit code would be used on the post-test packets. Thirty-four out of thirty-seven students enrolled in the course completed both pre and post-tests, 
however scores from four participants could not be matched with pre-test scores, resulting in a usable response rate of $85.7 \%(N=30)$.

\section{Instruments}

The two constructs investigated were (a) multicultural counseling self-efficacy (Multicultural Counseling Self-Efficacy Scale-Racial Diversity Form [MCSE-RD]; Sheu \& Lent, 2007) and (b) multicultural counseling competence (Multicultural Awareness, Knowledge, and Skills Survey - Counselor Edition - Revised [MAKSS-CE-R]; Kim, Cartwright, Asay, \& D'Andrea, 2003). The covariate used was social desirability as measured by the Marlowe-Crowne Social Desirability - Short Form (MCSD-SF; Reynolds, 1982). A demographic form was included in the pre-test assessment packet.

MCSE-RD. The MCSE-RD is a Likert-type scale consisting of 37 items designed to measure participants' confidence in their own ability to counsel clients who are racially different from themselves. The MCSE-RD is made up of three subscales: (a) Multicultural Intervention (MI), (b) Multicultural Assessment (MA), and (c) Multicultural Session Management (MSM). Questions ask the degree to which participants feel confident in their ability to perform counseling behaviors with clients different from themselves. Answers can range from " 0 " being "no confidence at all" to "9" being "complete confidence". Examples of items include "Openly discuss cultural differences and similarities between the client and yourself." and "Select culturally appropriate assessment tools according to the client's cultural background." Scores are obtained by averaging all 37 items to get the full-scale score and by utilizing mean scores from each of the subscales to look at specific areas of MCSE.

According to Sheu and Lent (2007), the MCSE-RD has high internal reliability with Cronbach's alphas ranging from .92 to .98 . The two-week test-retest reliability correlations of the subscales ranged from .69 to .88 with the total score reliability correlation being .77 (Sheu \& Lent, 2007). The three subscales were highly correlated with each other (correlation coefficients between .67 and .85$)$ and with the total scale score $(r>.83)$. In the current study the total scale reliability was .98 , the reliability for MI was .97 , for MA was .95 , and for MSM was .92 .

MAKSS-CE-R. The MAKSS-CE-R is a 33-item scale with three subscales; AwarenessRevised (Awareness-R), Knowledge-Revised (Knowledge-R), and Skills-Revised (Skills-R). It is designed to address the three areas of the tripartite model of multicultural competence; knowledge, awareness, and skills. Awareness-R is made up of 10 items, Knowledge-R has 13 items, and Skills$\mathrm{R}$ also has 10 items. Responses are given on three different four-point Likert-type scales. Possible responses range from (a) " 1 " indicating very limited to " 4 " being very aware, with items consisting of statements such as "At this time in your life, how would you rate yourself in terms of understanding how your cultural background has influenced the way you think and act?" (b) "1" being very limited to "4" indicating very good, with items consisting of statements such as "How would you rate your ability to effectively secure information and resources to better serve culturally different clients?" and (c) "1" meaning strongly disagree to "4" being strongly agree with items consisting of statements such as "The criteria of self-awareness, self-fulfillment, and self-discovery are important measures in most counseling sessions."

Kim et al. (2003) tested the reliability of the three subscales with two different samples. The reliability was high in both with alpha coefficients ranging from .71 for the Awareness-R subscale to .85 for the Knowledge-R subscale for the first sample and from .80 for the Awareness$\mathrm{R}$ to .87 for the Knowledge- $\mathrm{R}$ in the second sample (Kim et al, 2003). Reliability for the full scale 
MAKSS-CE-R was .82 and .81 for each respective sample. In the current study the reliability, was. 80 for the full scale, .69 for the Awareness-R subscale, .82 for Knowledge-R subscale, and .80 for Skills-R subscale.

MCSD-SF. Researchers (Constantine \& Ladany, 2000) indicate that counselor trainees are prone to responding to assessments on sensitive topics such as MCC in socially desirable ways, or ways that are pleasing to the researcher in an effort to appear better or more competent (Mcbride \& Hays, 2012). Self-report MCC has been significantly related to social desirability scores (Constantine \& Ladany, 2000; Liu, Sheu, \& Williams; 2004; Sodowsky, Kuo-Jackson, Richardson, $\&$ Corey, 1998). For example, higher scores on the knowledge subscale of the MAKSS was related to higher social desirability scores on the Marlowe-Crowne Social Desirability Scale (MCSDS, Constantine \& Ladany, 2000), a widely used and validated scale to assess the construct of social desirability (Barger, 2002).

Given the proneness to respond in socially desirable ways, we utilized the Reynolds's short version of the Marlowe-Crowne Social Desirability-Short Form (MCSD-SF; 1982) in the current investigation. The MCSD-SF is a 13-item scale consisting of true-false questions. The short form of the scale was developed by Reynolds (1982) to provide a valid and reliable version of the original 33-item scale by Crowne and Marlowe (1960) that would be easier to administer and require less time from participants. The 13-item measure's reliability was acceptable with a correlation coefficient of .76. Concurrent validity for the MCSCS-SF was established through correlation with the original 33-item scale. The 13-item measure was highly correlated with the original scale with a product-moment correlation coefficient of .93. In the current study reliability, as indicated by Cronbach's alpha, was .62.

\section{Results}

\section{Data Analysis}

A pre- post-test design was utilized for this research with the multicultural counseling class as an intervention. After the data collection process, raw data was entered into SPSS (Version 21.0), scored, and analyzed using Pearson product-moment correlations and a multivariate analysis of variance (MANOVA) to answer the primary research question. We used the full-scale mean scores for the MCSE-RD per the scoring instructions and the sum of scores for the MCSD-SF and the MAKSS-CE-R. Subscale scores for the MCSE-RD and the MAKSS-CE-R were used to provide further information per the instructions of the instruments. Prior to data analysis, all data was cleaned to look for outliers and assessed for assumptions of statistical analyses such as normality, homogeneity of variance, linearity, and multicollinearity. Data analyses indicated that no assumptions were violated.

\section{Participant Characteristics}

Descriptive data and frequencies indicated that the majority of the participants were female $(90 \%, n=27)$, with fewer males $(10 \%, n=3)$. Participants were mostly White/Caucasian $(n=21$, $70 \%)$, with three (10\%) participants identifying as African-American/Black, three (10\%) as AsianAmerican, two (6.7\%) as Hispanic, and one (3.3\%) who self-identified as "Other." The majority of participants $(66.7 \%, n=20)$ had no prior clinical experience though six participants $(20 \%)$ had completed one semester of practicum, one participant $(3.3 \%)$ had completed two semesters of 
practicum, one participant $(3.3 \%)$ had both two semesters of practicum and one semester of internship, and two (6.7\%) had completed two semesters of internship. Some participants had prior multicultural/ diversity training $(n=17,56.7 \%)$ and others $(n=13,43.3 \%)$ had no prior training.

\section{Social Desirability}

To assess the relationship between the construct of social desirability, as measured by the pretest scores on the MCSD-SF $(M=19.27, S D=2.59)$, and pretest scores on the MCSE-RD $(M$ $=5.65, S D=1.24)$ and the MAKSS-CE-R $(M=87.36, S D=7.07)$, a Pearson-product moment correlation (two-tailed) analysis was utilized. Pretest scores on the MCSD-SF and the MCSE-RD were statistically significantly correlated $(r=.42, p<.05)$ indicating a relationship between the constructs social desirability and MCSE. However this relationship was not supported by correlations $(r=.14, p>.05)$ of the posttest scores on the MCSD-SF $(M=19.27, S D=2.57)$ and the MCSE-RD $(M=6.56, S D=.95)$. This may indicate that the intervention affected the relationship between the constructs social desirability and MCSE. There was no statistically significant relationship between pre- or post-test scores on the MCSD-SF and the MAKSS-CE-R indicating no relationship between the constructs social desirability and MCC. There was a statistically significant relationship between scores on the pretest of the MCSE-RD and the MAKSS-CE-R $(r=.49, p<.01)$. There was also a statistically significant relationship between posttest scores on the MCSE-RD and the MAKSS-CE-R $(M=94.91, S D=10.30 ; r=.72, p<$ .001 ), indicating that the relationship between the constructs MCSE and MCC was stable and did not change over time or with the intervention.

\section{Differences in MCSE and MCC}

The primary research question was whether a semester long multicultural counseling course with a pedagogical emphasis of film affected MCSE and MCC. A repeated measure multivariate analysis of variance (MANOVA) was utilized to examine pre/post differences in MCSE and MCC utilizing full-scale scores on the MCSE-RD and the MAKSS-CE-R respectively. Due to lack of significance of correlations between the dependent variables and social desirability, MCSDS-SF was not included as a covariate so a repeated measure MANCOVA was not selected as an analysis. Results indicated that there was a statistically significant difference in scores across time, $F(1,20)=17.91, p<.001$, with scores on the MCSE-RD increasing from pre-test $(M=5.65$ $S D=1.24)$ to post-test $(M=6.56, S D=.95)$ and scores on the MAKSS-CE-R increasing from pretest $(M=87.36, S D=7.07)$ to post-test $(M=94.91, S D=10.30)$. Therefore, both MCC and MCSE scores improved across time, which indicates that the intervention seems to have had a positive impact on those scores. The practical significance (effect size) of these differences is high with $47.2 \%$ of the variance explained (utilizing eta squared of .472). The power to detect this difference was .98 .

The ascertain the difference of each construct across time, a repeated measures analysis of variance (ANOVA) was conducted with full-scales on the MCSE-RD and another with full-scale scores on the MAKSS-CE-R. There was a statistically significant difference between pretest MCSE-RD scores $(M=5.65 S D=1.24)$ and posttest MCSE-RD scores $(M=6.56, S D=.95), F$ $(1,28)=18.14, p<.001$. The practical significance (effect size) is moderate with $39.3 \%$ of variance explained (utilizing eta squared of .393). The power to detect this difference in scores 
was .98. There was also a statistically significant difference between pretest MAKSS-CE-R scores $(M=87.36, S D=7.07)$ and posttest MAKSS-CE-R scores $(M=94.91, S D=10.30), F(1,21)=$ $14.90, p<.01$. The practical significance (effect size) according to eta squared (.415) was high with $41.5 \%$ of variance explained and the power to detect this difference was .96 .

\section{Discussion}

The purpose of this investigation was to assess changes in scores on MCC and MCSE for counselor trainees as a result of engaging in a multicultural counseling course with an emphasis on film as a primary experiential pedagogy. Specifically, results from this study indicate that MCSE and self-reported MCC of counselor education students were both increased through their participation in an experiential multicultural counseling course that utilized film as the primary pedagogical strategy. Given the lack of empirical research on the use of film in multicultural training, this study provides initial support for this pedagogical approach. Furthermore, results from this investigation support previous research (Arthur \& Achenbach, 2002; Coleman, 2006) on the efficacy of experiential pedagogy in multicultural counseling courses, therefore continuing empirical research in the area of experiential pedagogy and cultural sensitivity. Furthermore this research supports the findings of other researchers advocating for the inclusion of experiential pedagogies in multicultural training in counselor preparation programs (Barden \& Cashwell, 2014; Collins \& Pieterse, 2007; Hill, 2003; Tyler \& Guth, 1999; Villalba \& Redmond, 2008).

Experiential learning can be used to raise awareness about multicultural issues, to challenge students' personal frameworks about cultural diversity, help students develop cultural empathy (Pope-Davis et al., 1997), and help counselors learn to stay in therapeutic relationships at difficult times. Given that graduates of counselor preparation programs have historically felt unprepared to counsel clients from culturally diverse backgrounds (Arthur \& Achenbach, 2002; D'Andrea \& Daniels, 2001), focusing on effective pedagogical approaches is paramount in the development of effective counselor preparation programs. Instructors of multicultural courses always need to conduct both formative and summative evaluations in order to ascertain the effectiveness of their pedagogical approaches, particularly experiential approaches, which have less empirical support. Yet researchers (Barden \& Cashwell, 2014; Collins \& Pieterse, 2007; Hill, 2003;Tyler \& Guth, 1999; Villalba \& Redmond, 2008) support the use of experiential strategies as pedagogical tools in multicultural training. This research provides initial support for the efficacy of a particular pedagogical technique on increasing MCC and MCSE in counseling students however to truly tailor a course to students, results from formative assessments should be attended to throughout a course, making adjustments as needed. For example, if students in a multicultural course indicate low self-efficacy at midterm, the instructor may consider reevaluating instructional strategies and activities planned to include more experiences that may be beneficial in increasing efficacy, such as including direct interactions with persons from diverse backgrounds (Coleman, 2006). In addition to experiential strategies such as direct interaction, which may be more difficult to coordinate, this research supports the use of film as an experiential strategy to supplement to increase MCSE, if that is a concern noted with formative assessments. Since film as a pedagogical tool, in conjunction with other experiential strategies, also seems to lead to an increase in selfreported MCC, film could be used when aspects of MCC are low, as indicated by formative assessments.

Additionally, processing and debriefing are a necessary part of utilizing experiential strategies and have been directly related to the effectiveness of experiential activities as a

Journal of the Scholarship of Teaching and Learning, Vol. 14, No. 5, December 2014. 
pedagogical tool (Achenbach \& Arthur, 2002; Arthur \& Achenbach, 2002; Kolb 1984; Villalba \& Redmond, 2008). Therefore, participants in this investigation were challenged to engage in conversations to duplicate a respectful, genuine, empathic therapeutic relationship by asking them to restate comments as if they were talking to clients. This was particularly helpful after watching the films, which aided the processing and application of the experiential learning. Although we cannot be certain that this form of reflection was directly beneficial in the increase self-reported MCC and MCSE, having students understand their peers' worldviews by increasing empathy through restating comments appeared to be helpful in increasing communication and understanding between students within the class discussions. This increase in communication appeared to lead to a greater understanding of other students in the class and the cultural base of their experiences. In sum, this research investigation has provided initial empirical support for the utility of experiential pedagogy in multicultural counselor education and the used of film specifically as an experiential pedagogical tool in a multicultural counseling course.

\section{Limitations}

Results from this study offer insight into the influence of film as a pedagogical tool in increasing multicultural competence and efficacy for counselor education students. Nevertheless, the results need to be interpreted within the context of study limitations. Limitations of this study include sampling and data collection procedures. Due to the voluntary nature of participation as well as the non-random nature of the sampling procedure, participants may have had different characteristics from those who did not participate. Additionally, participants were from a small convenience sample from one university, therefore the results of this study are not widely generalizable. Another limitation of this study is that the data collection instruments were solely self-report measures, which can be adversely impacted by socially desirable response tendencies. Although attempts were made to control for the tendency to respond in socially desirable ways, relying on self-report measures is a limitation in all research studies investigating sensitive topics such as multiculturalism. Additionally, though journals were utilized for processing and as a way for the instructor to communicate with students, those entries were not part of the study. That would have provided valuable qualitative data and included the students' voices in the research.

\section{Suggestions for Future Scholarship}

This study provided an initial empirical exploration of the use of film as the primary pedagogical intervention in increasing multicultural competence and multicultural self-efficacy for counselors in training. In light of the aforementioned limitations, additional scholarship is warranted to further understand the influence of experiential interventions on the MCC and MCSE of counselor education students. There is a need for future researchers to include larger, more diverse samples to both replicate and extend these findings. Additional research could compare different experiential interventions and their relative influence on increasing MCC and MCSE. For example, researchers could compare and contrast groups of students that engaged primarily in didactic instruction (control group) compared to students who primarily engaged in experiential instruction such as using film, service learning, and awareness raising classroom activities (experimental group).

Future research could examine social desirability as a multicultural construct and explore multicultural social desirability as a potential covariate. Additionally further research would 
benefit from utilizing additional, more direct measure to assess MCC rather than relying solely on self-report measures. Options for more direct assessment could include case conceptualization through print or video presentation or even direct observation with consent from the counselor and client. Adding qualitative components to this body of research would be beneficial in getting more in depth information from the students in the class on their own learning and examining specific areas of student learning that may not yet be assessed through quantitative measures. Lastly, although this study yielded significant change in MCC and MCSE across the course of the semester, little is known about the sustainability of these changes. Future scholarship using longitudinal designs would greatly contribute to our understanding of the development and sustainability of MCC and MCSE in practicing counselors.

\section{Conclusion}

In sum, rapidly changing demographic shifts in the United States highlight the need for counselors to be well prepared in working with clients from diverse backgrounds (TomlinsonClarke \& Clarke, 2010). Researchers (Arthur \& Achenbach, 2002; Coleman, 2006; Kim \& Lyons, 2003) emphasize that experiential pedagogical approaches enhance the effectiveness of multicultural counselor training beyond the traditional approach. The current study provides ample ground for further scholarship on the influence of film in increasing multicultural sensitivity and self-efficacy for counselor trainees.

\section{References}

Achenbach, K., \& Arthur, N. (2002). Experiential learning: Bridging theory to practice in multicultural counseling. Guidance and Counseling, 17, 39-45.

Alexander, C. M., Kruczek, T., \& Ponterotto, J. G. (2005). Building multicultural competencies in school counselor trainees: An international immersion experience. Counselor Education and Supervision, 44 (4), 255-266. doi: 10.1002/j.1556-6978.2005.tb01754.x

American Counseling Association. (2005). ACA code of ethics. Alexandria, VA: Author

Arredondo, P., \& Toporek, R. (2004). Multicultural counseling competencies = ethical practice. Journal of Mental Health Counseling, 26, 44-55.

Arthur, N., \& Achenbach, K. (2002). Developing multicultural counseling competencies through experiential learning. Counselor Education and Supervision, 42, 2-14. doi: 10.1002/j.15566978.2002.tb01299.x

Atlas, M. R., Brown, E., LaVoo, G. (Producers), \& Cardoso, P. (Director). (2002). Real women have curves [Motion picture]. United States: HBO Films, Newmarket Films (LaVoo Productions).

Barden, S. M., \& Cashwell, C. (2014). International immersion: An exploratory study of critical factors and counselor development. Journal of Multicultural Counseling and Development, 42, 42-60. doi: 10.1002/j.2161-1912.2014.00043.x 
Bandura, A. (1999). Moral disengagement in the perpetration of inhumanities. Personality \& Social Psychology Review, 3 (3), 193-209. doi: 10.1207/s15327957pspr0303_3

Bobby, C. L. (2013). The evolution of specialties in the CACREP standards: CACREP's role in unifying the profession. Journal of Counseling \& Development, 91, 35-43. doi: 10.1002/j.15566676.2013.00068.x

Briam, C. (2010). Outsourced: Using a comedy film to teach intercultural communication. Business Communication Quarterly, 73 (4), 383-398. doi: 10.1177/1080569910385567

Chambliss. C., \& Magakis, G. (1996). Videotapes for use in teaching psychopathology. (ERIC Document Reproduction Service No. ED 395 243)

Chao, R. C. (2012) Racial/ethnic identity, gender-role attitudes, and multicultural counseling competence: The role of multicultural counseling training. Journal of Counseling \& Development, 90, 35-44. doi: 10.1111/j.1556-6676.2012.00006.x

Coleman, M. N. (2006). Critical incidents in multicultural training: An examination of student experiences. Journal of Multicultural Counseling and Development, 34 (3), 168-182. doi: 10.1002/j.2161-1912.2006.tb00036.x

Collins, N. M., \& Pieterse, A. L. (2007). Critical incident analysis based training: An approach for developing active racial/cultural awareness. Journal of Counseling \& Development, 85, 1423. doi: 10.1002/j.1556-6678.2007.tb00439.x

Constantine, M. G. (2001). Multiculturally-focused counseling supervision: Its relationship to trainees' multicultural counseling self-efficacy. Clinical Supervisor, 20, 87. doi: 10.1300/J001v20n01_07

Constantine, M. G., \& Ladany, N. (2001). New visions for defining and assessing multicultural counseling competence. In J. G. Ponterotto, J. M. Casas, L. A. Suzuki, \& C. M. Alexander (Eds.). Handbook of multicultural counseling. (2nd ed.) Thousand Oaks, CA: Sage.

Cordero, A., \& Rodriguez, L. N. (2009). Fostering cross-cultural learning and advocacy for social justice through an immersion experience in Puerto Rico. Journal of Teaching in Social Work, 29 (2), 134-152. doi: 10.1080/08841230802238195

Council for Accreditation of Counseling and Related Educational Programs. (2009). The 2009 standards. Alexandria, VA: Author.

D'Andrea, M., \& Daniels, J. (2001). Expanding our thinking about white racism: Facing the challenge of multicultural counseling in the $21^{\text {st }}$ century. In J.G. Ponterrotto, J. M. Casas, L.A. Suzuki, \& C.M. Alexander (Eds.). Handbook of multicultural counseling ( $2^{\text {nd }}$ ed.) Thousand Oak, CA: Sage. 
DeRicco, J. N., \& Sciarra, D. T. (2005). The immersion experience in multicultural counselor training: Confronting covert racism. Journal of Multicultural Counseling and Development, 33, 2-16. doi: 10.1002/j.2161-1912.2005.tb00001.x

Dinsmore, J. A., \& England, J. T. (1996). A study of multicultural counseling training at CACREP-accredited counselor education programs. Counselor Education And Supervision, 36 (1), 58-76. doi: 10.1002/j.1556-6978.1996.tb00236.x

Dor-Ner, Z. (Producer), \& Bloomstein, R. (Director). (1993). The longest hatred [Motion picture]. United States: WGBH Boston.

Gladstein, G. A., \& Feldstein, J. C. (1983). Using film to increase counselor empathic experiences. Counselor Education and Supervision, 23, 125-131. doi: 10.1002/j.15566978.1983.tb00596.x

Cheadle, D. (Producer), \& Haggis, P. (Director). (2004). Crash (Motion picture). United States: Bob Yart Productions-De J Productions-Lions Gate Films.

Hays, D. G., Dean, J. K., \& Chang, C. Y. (2007). Addressing privilege and oppression in counselor training and practice: A qualitative analysis. Journal of Counseling \& Development, 85, 317-324. doi: 10.1002/j.1556-6678.2007.tb00480.x

Heppner, M. J., \& O’Brien, K. M. (1994). Multicultural counselor training: Students' perceptions of helpful and hindering events. Counselor Education and Supervision, 34, 4-18. doi: 10.1002/j.1556-6978.1994.tb00306.x

Herbes, C. (Writer \& Director). (2003). RACE - The Power of an Illusion: Episode 1 [Television series]. In L. Adelman \& C. Herbes (Producers). San Francisco, CA: California Newsreel.

Hill. N. R. (2003). Promoting and celebrating multicultural competence in counselor trainees. Counselor Education and Supervision, 43, 39-51. doi: 10.1002/j.1556-6978.2003.tb01828.x

Kim, B. S. K., Cartwright, B. Y., Asay, P. A., \& D’Andrea, M. J. (2003). A revision of the Multicultural Awareness, Knowledge, and Skills Survey - Counselor Edition. Measurement and Evaluation in Counseling and Development, 36, 161-180.

Kim, B. S. K., \& Lyons, H. Z. (2003). Experiential activities and multicultural counseling competence training. Journal of Counseling and Development, 81, 400-408. doi:

10.1002/j.1556-6678.2003.tb00266.x

Koch, G., \& Dollarhide, C. T. T. (2000). Using a Popular Film in Counselor Education: "Good Will Hunting" as a Teaching Tool. Counselor Education And Supervision, 39 (3), 203-210. doi: 10.1002/j.1556-6978.2000.tb01232.x

Kolb, D. A. (1984). Experiential learning. Englewood Cliffs, New Jersey: Prentice-Hall, Inc. 
Larson, L. M., \& Daniels, J. A. (1998). Review of the counseling self-efficacy literature. The Counseling Psychologist, 26 (2), 179-218. doi: 10.1177/0011000098262001

Locke, D., \& Kiselica, M. (1999). Pedagogy of possibilities: Teaching about racism in multicultural counseling courses. Journal of Counseling and Development, 77 (1), 80-86. doi: 10.1002/j.1556-6676.1999.tb02424.x

Minton, C. A. B. (2011). Using Real Women Have Curves to facilitate cultural perspective taking. In M. Pope, J. S. Pangelinan, \& A. D. Coker (Eds.), Experiential Activities for Teaching Multicultural Competence in Counseling (311-313). Alexandria, VA: American

Nixon, D.H., Marcelle-Coney, D., Torres-Greggory, M., Huntley, E., Jacques, C., Pasquest, M., \& Ravachi, R. (2010). Creating community: Offering a liberation pedagogical model to facilitate diversity conversation in MFT graduate classrooms. Journal of Marital and Family Therapy, 36 (2), 197-211. doi: 10.1111/j.1752-0606.2009.00180.x

Orlinksy, D. E., Grawe, L., \& Parks, B. K. (1994). Process and outcome in psychotherapy. In A. E. Bergin \& S. L. Garfield (Eds.), Handbook of psychotherapy and behavior change (pp. 270 376). New York: Wiley.

Pandey, S. (2012). Using popular movies in teaching cross-cultural management. European Journal of Training and Development, 36, 329-350. doi: 10.1108/03090591211204779 Pinterits, E., \& Atkinson, D. R. (1998). The diversity video forum: An adjunct to diversity sensitivity training in the classroom. Counselor Education and Supervision, 37 (3), 203-16. doi: 10.1002/j.1556-6978.1998.tb00545.x

Ponterotto, J. G. (1997). A competency model and national survey. Multicultural Counseling Competencies: Assessment, Education, Training, and Supervision, 111.

Pope-Davis, D. B., Liu, W. M., Nevitt, J., \& Toporek, R. L. (2000). The development and initial validation of the Multicultural Environmental Inventory: A preliminary investigation. Cultural Diversity and Ethnic Minority Psychology, 6 (1), 57-64. doi: 10.1037/1099-9809.6.1.57

Priester, P. E., Jones, J. E., Jackson-Bailey, C. M., Jana-Masri, A., Jordan, E. X., \& Metz, A. J. (2008). An analysis of content and instructional strategies in multicultural counseling courses.

Journal of Multicultural Counseling \& Development, 36, 29-39. doi:

10.1002/j.2161-1912.2008.tb00067.x

Reynolds, W. M. (1982). Development of reliable and valid short forms of the Marlowe-Crowne social desirability scale. Journal of Clinical Psychology, 38, 119-125. doi: 10.1002/10974679(198201)38:1<119::AID-JCLP2270380118>3.0.CO;2-I

Roell, C. (2010). Intercultural training with films. English Teaching Forum, 2, 2-15.

Rorrer, A. A., \& Furr, S. (2009). Using film as a multicultural awareness tool in teacher education. Multicultural Perspectives, 11 (3). 162-168. doi: 10.1080/15210960903116902 
Sheu, H. B., \& Lent, R. W. (2007). Development and initial validation of the multicultural counseling self-efficacy scale-racial diversity form. Psychotherapy: Theory, Research, Practice, Training, 44 (1), 30-45. doi: 10.1037/0033-3204.44.1.30

Smith. L. M. (Writer \& Director). (2003). RACE - The Power of an Illusion: Episode 3 [Television series]. In L. Adelman \& L. M. Smith (Producers). San Francisco, CA: California Newsreel.

Strain, T. H. (Writer \& Director). (2003). RACE - The Power of an Illusion: Episode 2 [Television series]. In L. Adelman \& T. H. Strain (Producers). San Francisco, CA: California Newsreel.

Sue, D. W. (1981) Counseling the culturally different: Theory and practice. New York: Wiley.

Sue, D. W., Arredondo, P., \& McDavis, R. J. (1992). Multicultural counseling competencies and standards: A call to the profession. Journal of Counseling \& Development, 70 (4), 477-486. doi: 10.1002/j.1556-6676.1992.tb01642.x

Tomlinson-Clarke, S. M., \& Clarke, D. (2010). Culturally focused community-centered service learning: An international cultural immersion experience. Journal of Multicultural Counseling and Development, 38 (3), 166-175. doi: 10.1002/j.2161-1912.2010.tb00124.x Tyler, J. M., \& Guth, L. J. (1999). Using media to create experiential learning in multicultural and diversity issues. Journal of Multicultural Counseling and Development, 27, 153-165. doi: 10.1002/j.2161-1912.1999.tb00221.x

Villalba, J. A., \& Redmond, R. E. (2008). Crash: Using a popular film as an experiential learning activity in a multicultural counseling course. Counselor Education \& Supervision, 47, 264-276. doi: 10.1002/j.1556-6978.2008.tb00056.x

Weaver, H. N. (2005). Explorations in cultural competence: Journeys to the four directions. Belmont, CA: Thomson Brooks/Cole. 